\title{
Gene expression in liver and adipose tissue is altered during and after temporary changes to postpartum milking frequency
}

\author{
T. M. Grala, ${ }^{\star 1}$ C. V. C. Phyn,† J. K. Kay, † A. G. Rius, $†$ M. C. Lucy, $\ddagger$ M. D. Littlejohn, ${ }^{\star 2}$ R. G. Snell,§ \\ and J. R. Roche† \\ ${ }^{*}$ DairyNZ c/o University of Auckland, 3A Symonds St, Auckland, 1010, New Zealand \\ †DairyNZ, Cnr Ruakura and Morrinsville Rds, Newstead, Hamilton, 3286, New Zealand \\ $\ddagger$ Animal Sciences, University of Missouri, Columbia 65211 \\ §University of Auckland, 3A Symonds St, Auckland, 1010 New Zealand
}

\section{ABSTRACT}

Short-term changes to milking frequency can alter the metabolic status of dairy cows depending on the duration, magnitude, and stage of lactation at which the milking frequency changes occur. Additionally, effects of altered milking frequency that are subsequent to cows returning to a normal twice-daily $(2 \times)$ milking regimen are not well established. This study tested the hypothesis that plasma concentrations of key hormones and metabolites and transcription of genes involved in the somatotropic axis and lipid metabolism would be altered in liver and subcutaneous adipose tissue from cows milked with different frequencies. Multiparous Holstein-Friesian dairy cows were allocated to $2 \times$ milking for the whole lactation, or once- $(1 \times)$ or 3 times- $(3 \times)$ daily milking for 3 or $6 \mathrm{wk}$, immediately postpartum, and then $2 \times$ milking for the remainder of the lactation. Liver and subcutaneous fat were biopsied at wk 1 (liver only), 3, 6, and 9 postpartum, and transcription of genes involved in the somatotropic axis and lipid metabolism were measured. At wk 3, cows milked $3 \times$ had lower hepatic expression of growth hormone receptor $(G H R 1 A)$ compared with cows milked $2 \times$ or $1 \times$, and lower $I G F 1$ expression compared with cows milked $1 \times$, indicating greater uncoupling of the somatotropic axis. At wk 6 , reduced transcription of total $G H R$ and $G H R 1 B$ occurred in the adipose tissue of cows milked $3 \times$. Cows milked $1 \times$ had greater transcription in adipose tissue of lipogenesis genes at wk 3 and 6 , and lipolysis genes at wk 6 , compared with cows milked $2 \times$, indicating a period of increased fatty acid storage, followed by increased fatty acid reesterification. At wk 9, cows previously milked $3 \times$ for 6 wk maintained lower transcription of genes involved in lipogenesis, lipolysis, and ketolysis in adipose tissue compared with cows milked $2 \times$, indicat-

Received May 14, 2013.

Accepted February 4, 2014.

${ }^{1}$ Corresponding author: talia.grala@dairynz.co.nz

${ }^{2}$ Current address: LIC, Cnr Ruakura and Morrinsville Rds, Newstead, Hamilton, New Zealand. ing that the effects of $3 \times$ milking persist for at least 3 wk after switching to $2 \times$ milking. Results indicate that alterations to milking frequency affect the transcription of genes involved in lipid mobilization and storage, enabling the animal to manage the energy demands associated with the change in milk production. Some of these gene transcription changes were maintained in cows previously milked $3 \times$, indicating that the adipose tissue gene expression changes were still required even after $3 \mathrm{wk}$ of the less-demanding $2 \times$ milking regimen.

Key words: energy balance, somatotropic axis, early lactation, lipid metabolism

\section{INTRODUCTION}

During early lactation, homeorhetic changes ensure that nutrients are partitioned toward milk production at the expense of tissue reserves (Bauman and Currie, 1980). These changes include a period of insulin resistance (Bell and Bauman, 1997; Vernon and Pond, 1997) and the uncoupling of the somatotropic axis, which is reflected by decreased growth hormone (GH) receptor (GHR) expression in the liver (Kobayashi et al., 1999). The reduced GHR expression limits the hepatic production of IGF-1 (Lucy et al., 2009), and decreases the negative feedback of IGF-1 on GH production (Rhoads et al., 2004). The insulin resistance, high plasma GH, and low IGF-1 concentrations act in coordination to minimize glucose uptake into muscle and adipose tissue (Chagas et al., 2009; Lucy et al., 2009), and enhance lipolysis in adipose tissue (McNamara and Hillers, 1986; Khan et al., 2013), which results in FA efflux and an increase in nutrient provision for milk production from body stores.

Altering milking frequency during early lactation may modify these homeorhetic mechanisms to support the corresponding change in milk production. Increasing the frequency of milking may exacerbate the negative energy balance, due to the expected increase in milk production and the limitations of nutrient intake, especially in pasture-based dairy systems. The severity 
of the negative energy balance may also depend on the duration of the change in milking frequency. Increasing the milking frequency from twice daily $(\mathbf{2} \times)$ to 3 times daily $(3 \times)$ for 8 wk reportedly increased milk production, but also increased metabolic stress for the duration of the study (Andersen et al., 2004b). However, increasing milking frequency from $2 \times$ to either $3 \times$ or 4 times daily for 3 or 4 wk immediately postpartum, does not evoke major metabolic effects (McNamara et al., 2008; Soberon et al., 2010).

Increasing milking frequency increases the plasma concentrations of NEFA and BHBA, which indicate increased lipolysis and ketogenesis (Loiselle et al., 2009; Soberon et al., 2010). Furthermore, Eslamizad et al. (2010) reported decreased BCS (a tool for assessing body fat reserves; Roche et al., 2004) and plasma glucose, but no change in hepatic triacylglyceride (TAG) concentration, in cows milked 6 times daily compared with cows milked $3 \times$. Additionally, limited data exist on any persistent or carryover effects of increased milking frequency on metabolic indices.

In comparison, decreasing milking frequency may improve energy balance. Cows milked once daily $(\mathbf{1} \times)$ have improved energy balance, reduced BCS loss, and reduced BW loss during early lactation (Patton et al., 2006; McNamara et al., 2008). The metabolic benefits of milking $1 \times$ during early lactation are consistent across studies; however, less information is available on metabolic effects of $1 \times$ milking once cows are switched to $2 \times$. In a recent study (Kay et al., 2013), decreasing milking frequency from $2 \times$ to $1 \times$ did not alter plasma GH concentrations; however, glucose, insulin, and IGF1 concentrations were greater, and BHBA and NEFA concentrations lower, in cows milked $1 \times$ compared with $2 \times$. Furthermore, after cows milked $1 \times$ were switched to $2 \times$ milking, glucose, insulin and IGF-1 concentrations tended to remain greater.

The milk production and BW measures from previous work (Phyn et al., 2011) indicate that metabolic changes occur in response to altered milking frequency and persist even when milked $2 \times$. Therefore, to increase understanding of the homeorhetic mechanisms responsive to milking frequency, plasma concentrations of key hormones and metabolites and transcription of genes involved in the somatotropic axis and lipid metabolism were measured in liver and subcutaneous adipose tissue from cows milked with different frequencies during the period immediately postpartum.

\section{MATERIALS AND METHODS}

\section{Experimental Design and Treatments}

The study was conducted at Lye Farm, DairyNZ (Hamilton, New Zealand; $37^{\circ} 46^{\prime} \mathrm{S}, 175^{\circ} 18^{\prime} \mathrm{E}$ ) from June to November 2009. All treatments and measurements were approved by the Ruakura Animal Ethics Committee (Hamilton, New Zealand).

The experimental design, grazing management, and supplementary feeding of cows are described in Phyn et al. (2011). Briefly, multiparous Holstein-Friesian and Holstein-Friesian $\times$ Jersey dairy cows $(\mathrm{n}=150)$ were randomly allocated to 1 of 5 treatments $(\mathrm{n}=30$ / treatment) immediately postpartum (mean $\pm \mathrm{SD}$; July $15,2009 \pm 10.6 \mathrm{~d})$. Treatments were (1) cows milked $2 \times$ for the entire lactation (control), (2) cows milked $1 \times$ for 3 wk postpartum and $2 \times$ thereafter, (3) cows milked $1 \times$ for 6 wk postpartum and $2 \times$ thereafter, (4) cows milked $3 \times$ for 3 wk postpartum and $2 \times$ thereafter, and (5) cows milked $3 \times$ for 6 wk postpartum and $2 \times$ thereafter. Daily milking times were $0700 \mathrm{~h}$ for $1 \times(24$ $\mathrm{h}$ interval), 0700 and $1500 \mathrm{~h}$ for $2 \times(16 / 8$-h interval), and 0700,1500 , and $2200 \mathrm{~h}$ for $3 \times(9 / 8 / 7$-h interval).

All cows were offered a generous allowance of perennial ryegrass/white clover pasture $(\sim 30$ to $45 \mathrm{~kg}$ of $\mathrm{DM} /$ cow per day measured to ground level with target postgrazing residuals of $1,800 \mathrm{~kg}$ of $\mathrm{DM} / \mathrm{ha}$ ). Cows grazed in $1 \times, 2 \times$, and $3 \times$ milking mobs in the same paddock separated by a wire so that they could be drafted independently to the farm dairy for milking. Due to the inherent difficulties of measuring individual DMI under grazing conditions, energy intakes per cow could not be measured, but high postgrazing residuals were targeted to ensure that DMI was not limited by pasture allocation. Furthermore, pasture silage was offered at, on average, $3.6 \mathrm{~kg}$ of DM/cow per day for 40 d during July and August to maintain pasture residuals when pasture availability was limited, and pasture quality was maintained by strategic mechanical cutting of high residuals or an immediate regrazing with a nontreatment group of cows. In addition, cows were offered $2 \mathrm{~kg}$ of $\mathrm{DM} / \mathrm{cow}$ per day of pelleted maize/ barley/molasses-based concentrate in 1 feed at $0900 \mathrm{~h}$ for 2 wk before their expected calving date. Following calving, the same concentrate was individually offered to cows at $4 \mathrm{~kg}$ of $\mathrm{DM} /$ cow per day during the a.m. milking until November 1 (i.e., 109 DIM) and at $2 \mathrm{~kg}$ of DM/cow per day thereafter, until November 24.

\section{Milk and Blood Sampling and Measurements}

Milk production and BCS measurements were as described elsewhere (Phyn et al., 2011). Briefly, individual milk yields and milk composition (fat, $\mathrm{CP}$, and lactose) were determined daily and weekly, respectively. Body condition score (1-10 scale, where $1=$ emaciated and 10 = obese; Roche et al., 2004) were measured once per week until September and once every 2 wk thereafter. Blood was sampled on the same $1 \mathrm{~d}$ each week for the 
first 12 wk postpartum. A 10-mL evacuated blood tube (Becton Dickinson, Franklin Lakes, NJ) containing 140 IU of sodium heparin was collected from each cow by coccygeal venipuncture immediately before the morning milking (approximately $0700 \mathrm{~h}$ ). Samples were placed on ice and then centrifuged at $1,120 \times g$ for 12 min at $4^{\circ} \mathrm{C}$. Plasma was harvested and stored at $-20^{\circ} \mathrm{C}$ while awaiting subsequent analyses for metabolites (NEFA and glucose), and hormones (growth hormone, GH, insulin, and IGF-1) as described in Grala et al. (2014).

Briefly, analyses for plasma concentrations of NEFA [acyl Co-A synthetase, acyl-CoA oxidase (ACS-ACOD) colorimetric method using the NEFA C Kit from Wako, Osaka, Japan] and glucose [glucose oxidase/4aminophenazone/phenol (GOD-PAP) method determined photometrically] were performed on a Modular P800 analyzer (Roche, Basel, Switzerland) at $37^{\circ} \mathrm{C}$ by Gribbles Veterinary Pathology Ltd. (Hamilton, New Zealand). The inter- and intraassay coefficients of variation were $<2 \%$ for all assays.

Plasma GH (Downing et al., 1995), IGF-1 (Gluckman et al., 1983), and insulin (Hales and Randle, 1963) were measured in duplicate by double-antibody RIA by the University of Western Australia (Perth, Australia) with inter- and intraassay coefficients of variation $<6 \%$. Validation for bovine plasma was as previously reported (Chagas et al., 2007).

Plasma GH measurements used ovine GH [NIDDKI-5; National Hormone and Pituitary Program of the National Institute of Diabetes and Digestive and Kidney Diseases (NHPP-NIDDK), Bethesda, MD] and anti-ovine GH antiserum (NIDDK-anti-oGH-3; NHPPNIDDK; final dilution 1:300,000). Plasma IGF-1 was assayed with human recombinant IGF-1 (ARM4050; Amersham-Pharmacia Biotech, Buckinghamshire, UK) and anti-human IGF-1 antiserum (AFP4892898; NHPP-NIDDK; final dilution 1:360,000) and insulin antiserum (GP2, 21/7/80), donated by Peter Wynn (Commonwealth Scientific and Industrial Research Organisation, Division of Animal Production, Blacktown, New South Wales, Australia), was raised in guinea pigs by using bovine insulin (BI 4499; Ely Lilly Pty. Ltd., West Ryde, Sydney, Australia).

\section{Tissue Sampling}

Liver and adipose tissue were collected at wk 1 (liver only), 3, 6, and 9 postpartum from a subset of cows $(\mathrm{n}=12 /$ treatment $)$. The wk-1 liver sample was only collected from cows in $2 \times, 1 \times$ for $3 \mathrm{wk}$, and $3 \times$ for 3 -wk treatment groups to minimize the number of cows subjected to 4 consecutive biopsies, as required for animal ethics approval. This encompassed all the treatments at this time point, as the effect of the dura- tion of altered milking frequency was not a factor until the wk-6 biopsy. Subsequent liver and adipose samples were collected from all treatments. Intravaginal controlled internal drug release (CIDR) devices (Zoetis, NSW, Australia) containing $1.38 \mathrm{~g}$ of progesterone were inserted $2 \mathrm{~d}$ before and removed at the wk-3 and -9 biopsies to prevent estrous behaviors around the time of the biopsy.

Liver sample collection was performed from an area in the eleventh intercostal space as described by Lucy et al. (1998), resulting in samples of approximately 200 mg. Subcutaneous adipose samples were collected posterior to the shoulder blade, and approximately $10 \mathrm{~cm}$ down the withers. The site was clipped and cleansed with iodine before local anesthetic (2\% lignocaine; Lopaine; Ethical Agents Ltd., Auckland, New Zealand) was administered. A $3-\mathrm{cm}$ incision was made through the skin, and 30 to $80 \mathrm{mg}$ of adipose tissue was removed using forceps and a scalpel. Biopsies were immediately placed in screw-capped microcentrifuge tubes and snapfrozen in liquid nitrogen. Samples were stored at $-80^{\circ} \mathrm{C}$ until RNA extraction (6 to 9 mo later).

\section{Extraction of RNA and cDNA Synthesis}

Total cellular RNA was isolated from the liver and adipose biopsies using a Qiagen RNeasy kit (Qiagen GmbH, Hilden, Germany). Liver biopsies of approximately $30 \mathrm{mg}$ were homogenized by adding 3 ball bearings of 3-mm diameter (Farrell Bearings Ltd., Hamilton, New Zealand) into a tube containing the biopsy and RLT lysis buffer (Qiagen $\mathrm{GmbH}$ ). Tubes were loaded into a TissueLyser II (Qiagen $\mathrm{GmbH}$ ) and homogenized for $2 \mathrm{~min}$. Total RNA was then extracted and treated with DNase (Ambion DNA-free kit; Ambion Inc., Austin, TX). Adipose biopsies of approximately $80 \mathrm{mg}$ were homogenized as described above before adding $200 \mu \mathrm{L}$ of chloroform and centrifuging at 12,000 $\times g$ for $15 \mathrm{~min}$ at $4^{\circ} \mathrm{C}$. Once the nucleic acids were separated from the protein and lipid globules, total RNA was extracted as above. The RNA quantity, purity, and integrity were determined by using a NanoDrop ND-1000 (NanoDrop Technologies LLC, Wilmington, DE) and the Agilent 2100 Bioanalyzer with an RNA 6000 Nano LabChip kit (Agilent Technologies Inc., Palo Alto, CA). All RNA samples were stored at $-80^{\circ} \mathrm{C}$.

Of the 216 planned liver biopsies, 200 yielded usable tissue samples, with RNA successfully extracted from 196 of these. Final numbers for each treatment group were as follows: $1 \times$ for 3 wk: total $\mathrm{n}=45,1$ wk: $\mathrm{n}=$ 10, 3 wk: $\mathrm{n}=12,6$ wk: $\mathrm{n}=12$, and 9 wk: $\mathrm{n}=11 ; 1 \times$ for 6 wk: total $\mathrm{n}=35,3$ wk: $\mathrm{n}=11,6$ wk: $\mathrm{n}=12,9$ wk: $\mathrm{n}=12 ; 2 \times$ : total $\mathrm{n}=45,1$ wk: $\mathrm{n}=11,3$ wk: $\mathrm{n}=$ 12,6 wk: $\mathrm{n}=11$, and 9 wk: $\mathrm{n}=11 ; 3 \times$ for 3 wk: total 
$\mathrm{n}=35,1$ wk: $\mathrm{n}=11,3$ wk: $\mathrm{n}=10,6$ wk: $\mathrm{n}=7$, and $9 \mathrm{wk}: \mathrm{n}=7$; and $3 \times$ for 6 wk: total $\mathrm{n}=36,3$ wk: $\mathrm{n}=$ 12, 6 wk: $\mathrm{n}=12$, and 9 wk: $\mathrm{n}=12$.

Of the 180 planned adipose biopsies, 176 yielded usable tissue samples, with RNA successfully extracted from 173 of these. Final numbers for each treatment group were as follows: $1 \times$ for 3 wk: total $\mathrm{n}=33,3 \mathrm{wk}$ : $\mathrm{n}=11,6$ wk: $\mathrm{n}=12$, and 9 wk: $\mathrm{n}=10 ; 1 \times$ for 6 wk: total $\mathrm{n}=36,3$ wk: $\mathrm{n}=12,6$ wk: $\mathrm{n}=12$, and 9 wk: $\mathrm{n}$ $=12 ; 2 \times:$ total $\mathrm{n}=36,3$ wk: $\mathrm{n}=12,6$ wk: $\mathrm{n}=12$, and 9 wk: $\mathrm{n}=12 ; 3 \times$ for 3 wk: total $\mathrm{n}=32,3$ wk: $\mathrm{n}=10$, 6 wk: $\mathrm{n}=11$, and $9 \mathrm{wk}: \mathrm{n}=11$; and $3 \times$ for $6 \mathrm{wk}$ : total $\mathrm{n}=36,3$ wk: $\mathrm{n}=12,6$ wk: $\mathrm{n}=12$, and 9 wk: $\mathrm{n}=12$.

Two micrograms of each liver RNA sample (final volume $=40 \mu \mathrm{L}$ ) and $0.25 \mu \mathrm{g}$ of each adipose RNA sample (final volume $=40 \mu \mathrm{L}$ ) were used for cDNA synthesis using the Invitrogen SuperScript III SuperMix kit (Invitrogen Corp., Carlsbad, CA). Total RNA was reverse transcribed according to the manufacturer's instructions, using a final concentration of $27 \mu M$ of random pentadecamer primers. Reverse-transcriptase negative controls were generated by excluding the enzyme. Resultant cDNA samples were stored at $-20^{\circ} \mathrm{C}$.

\section{Quantitative PCR and mRNA Analyses}

Using reverse-transcription quantitative PCR (RTqPCR) analysis, the expression of 25 target genes was determined in liver and adipose tissue (Table 1). Genes were targeted for their involvement in the somatotropic axis in liver ( $\mathrm{n}=6$ genes) and lipogenesis, lipolysis, and nutrient utilization in adipose $(\mathrm{n}=21$ genes $)$ tissue. The RT-qPCR was performed as described in Grala et al. (2011) using Roche real-time PCR master mix (LightCycler 480 Probes Master; Roche Diagnostics Deutschland GmbH, Mannheim, Germany) and Roche Universal Probe Library assays analyzed on the Roche LightCycler 480 system (Roche Diagnostics Deutschland $\mathrm{GmbH}$ ). Assays were designed to publicly available bovine gene sequences [National Center for Biotechnology Information (NCBI); http://www.ncbi.nlm.nih. gov/gene] using Roche Universal Probe Library design software. Assays were designed to span an intron-exon boundary of genes to prevent amplification of genomic DNA, and the specificity of PCR primers tested using the BLAST algorithm (http://blast.ncbi.nlm.nih.gov/; Altschul et al. 1990). The primer and probe sequences and location of the assays are presented in Table 1 . Primers were manufactured at $50 \mathrm{nmol}$ (Invitrogen Corp.) and purified by desalting. The RT-qPCR reaction volume was $10 \mu \mathrm{L}$, consisting of $4 \mu \mathrm{L}$ of cDNA and $6 \mu \mathrm{L}$ of master mix $(5 \mu \mathrm{L}$ of Roche Probes Master, $0.4 \mu \mathrm{L}$ of each $5 \mu \mathrm{M}$ primer, $0.075 \mu \mathrm{L}$ of probe, and $0.125 \mu \mathrm{L}$ of $\mathrm{H}_{2} 0$ ). Reactions were set up using an
epMotion 5075 robot (Eppendorf, North Ryde, NSW, Australia) before plates of samples were transferred into the LightCycler 480 instrument. Standard cycling conditions were used $\left[95^{\circ} \mathrm{C}\right.$ for $10 \mathrm{~min},\left(95^{\circ} \mathrm{C}\right.$ for $10 \mathrm{~s}$, $60^{\circ} \mathrm{C}$ for $\left.30 \mathrm{~s}\right) \times 45$ cycles, and $40^{\circ} \mathrm{C}$ for $\left.40 \mathrm{~s}\right]$.

To quantify gene expression, cDNA was diluted as per Table 1. Each RT-qPCR run included 2 negative controls (i.e., a no-template control with water added instead of cDNA and a reverse transcription negative control), and 3 interrun calibrators. Interrun calibrators were necessary, as the number of samples required 2 plates to be used for each gene (Hellemans et al. 2007). Triplicate measurements were performed for all samples and standard curves with standard deviations of less than 0.15 cycles were used for quantitation. Assays were tested for specificity by visualizing PCR products on an agarose gel (3\%) with expected amplicon specificity and length. The per-cycle amplification efficiency of the PCR assays ranged between 1.88 and 1.97.

The Roche LightCycler 480 software was used to analyze gene expression using relative standard curve second-derivative maximum analysis. A 6-point standard curve of serial cDNA dilutions was used, ranging from $3.33 \times 10^{-1}$ to $1.37 \times 10^{-3}$. Endogenous control genes were tested across all samples and their suitability determined using NormFinder and GeNorm software (Vandesompele et al., 2002; Andersen et al., 2004a). In liver tissue, RPS15A and YWAHZ were the 2 most stably expressed genes (0.086 and 0.090 stability values, respectively), and provided the best combination (0.074 stability value). In adipose tissue, the 2 most stably expressed genes were MRPL39 and EIF3K; however, NormFinder indicated that the best combination for elimination of treatment group bias was MRPL39 and ACTB (stability value of 0.087). The Roche LightCycler 480 software was then used to perform advanced relative quantification analysis of gene expression using the normalization factor of the 2 endogenous control genes. The geometric mean of the interrun calibrators was calculated for each plate and applied to each sample.

\section{Calculations and Statistical Analysis}

Production, BCS, Hormone, and Metabolite Data. Repeated measurements through time were modeled for milk production, BCS, and plasma hormone and metabolite data using cubic splines within the linear mixed model framework in GenStat software (version 13.2; VSN International Ltd., UK) as described by Verbyla et al. (1999; results not presented). Milking frequency $(1 \times, 2 \times$, or $3 \times)$, duration $(3$ or 6 wk), the linear trend of time, and their interaction were 
Table 1. Characteristics of gene-specific quantitative PCR assays

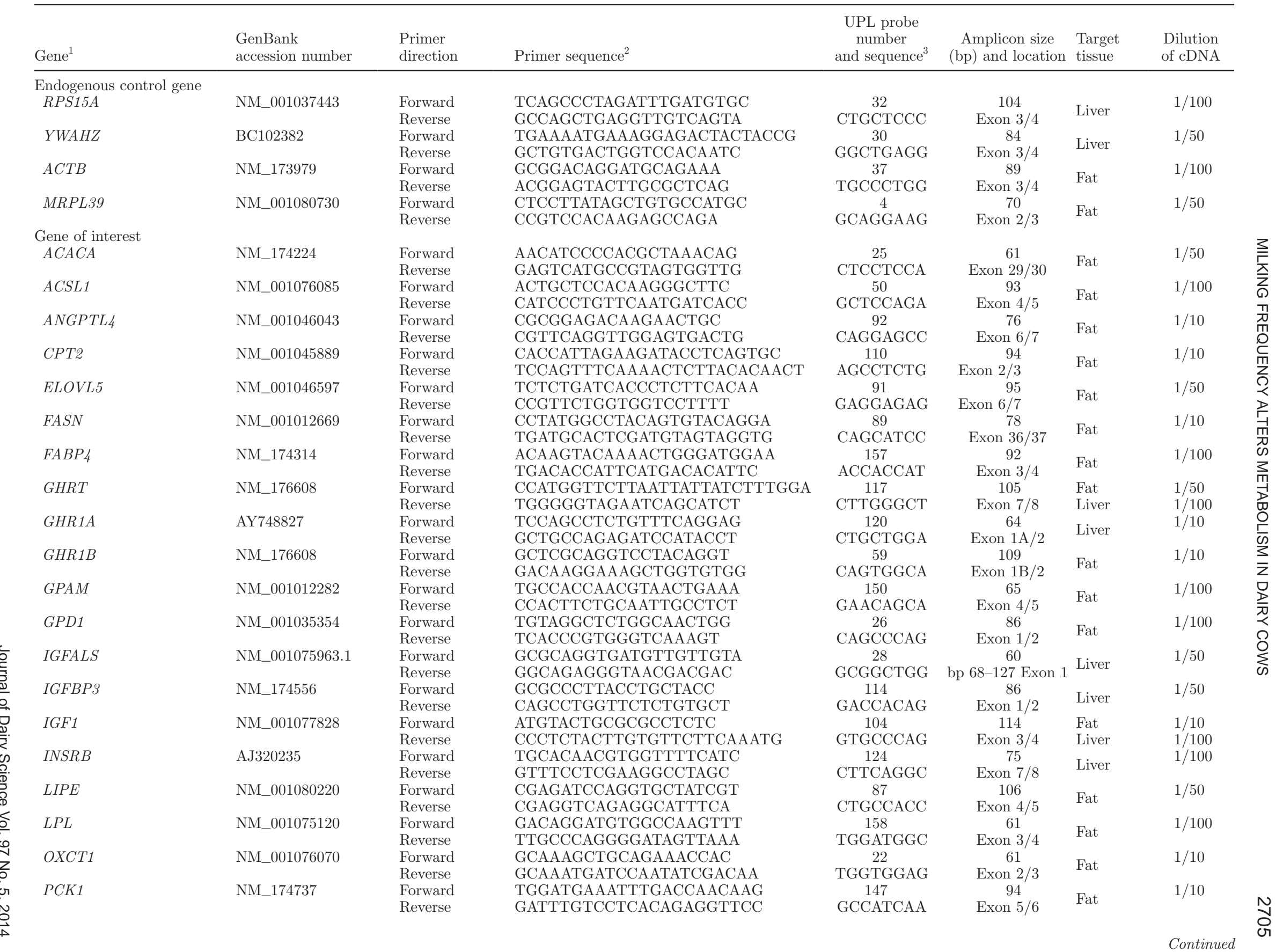




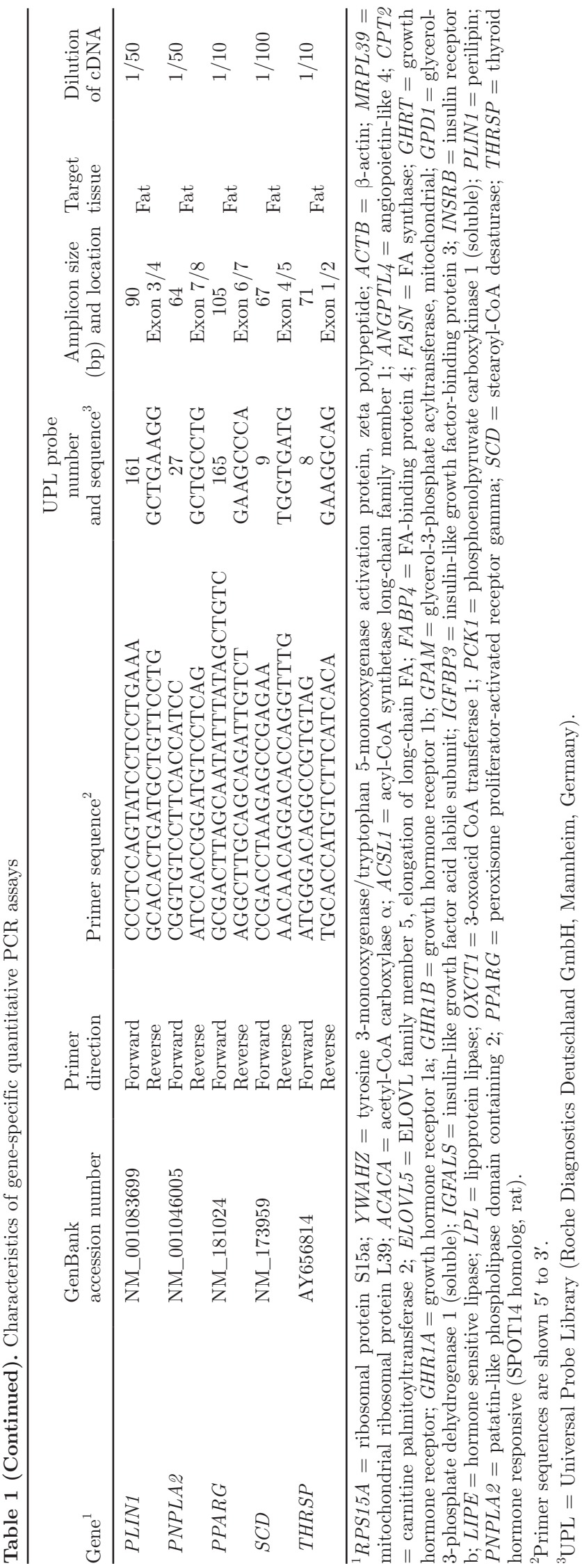

included as fixed effects, and cow, the linear trend of time within cow, spline, and the interaction of milking frequency and duration with spline were included as random effects. As treatment (milking frequency or duration or both) by time interactions $(P<0.05)$ were present, milk production, BCS, and plasma hormone and metabolite data were also analyzed at wk 1, 3, 6, and 9 using mixed models fitted with REML in GenStat, including treatment and contrasts to test milking frequency, duration, and their interaction as fixed effects, and cow as a random effect; $t$-tests were used for individual treatment comparisons if significant milking frequency by duration interactions were detected. Data for GH, insulin, and IGF-1 were logarithmically transformed before statistical analyses. Body condition score at 1 wk prepartum (mean $\pm \mathrm{SD} ; 5.1 \pm 0.5$ units) was used as a covariate for analysis of BCS data.

Data are presented as means with the standard error of the difference between the means (SED) for each treatment and time point. The SED $\times \sqrt{0.75}$ should be used to compare the mean of $1 \times$ or $3 \times$ treatments with each other and the $2 \times$ control. Differences in data were considered significant when $P<0.05$ and declared a trend when $P<0.10$.

Gene Expression Data. Data for each gene were logarithmically transformed before statistical analyses. Adipose gene expression data measured at 3 time points (wk 3, 6, and 9) were analyzed using a repeatedmeasures analysis as a mixed model in GenStat software, with cow as the random effect, and repeated measurements within cow modeled using a compound symmetry covariance structure including the fixed effects of time (wk), treatment, and their interaction. For most of the genes investigated, significant $(P<$ $0.05)$ interactions were detected between treatment and time. Therefore, further statistical analyses were then undertaken to explore the immediate effect of milking frequency at wk 3 , the interaction between milking frequency and duration at wk 6 , and the carryover effects of both milking frequency and milking frequency by duration at wk 9 when all cows had been switched to $2 \times$ milking. Adipose gene expression data at each time point were analyzed using mixed models fitted with REML in GenStat, including treatments and contrasts to test milking frequency, duration, and their interaction as fixed effects, and cow as a random effect. Liver gene expression data at each of the 4 time points (wk 1, 3,6 , and 9) were also analyzed using this same model for consistency. Repeated-measures analysis for liver gene expression data was not undertaken because liver biopsies were not collected at wk 1 from cows in the $1 \times$ for $6 \mathrm{wk}$ and $3 \times$ for $6 \mathrm{wk}$ treatments as described in the Tissue Sampling section above. 
In addition, $t$-tests were used for individual treatment comparisons if significant milking frequency by duration interactions were detected. Data are presented as means with the SED for each treatment and time point. The SED $\times \sqrt{0.75}$ should be used to compare the mean of $1 \times$ or $3 \times$ treatments with each other and the $2 \times$ control. Differences in data were considered significant when $P<0.05$ and declared a trend when $P<$ 0.10 .

\section{RESULTS}

\section{Milk Production, Body Condition, Plasma Hormone, and Metabolite Measurements}

Milk production measures and BCS are described in Phyn et al. (2011); however, relevant data at wk 1, 3, 6, and 9 are presented in Table 2 . In brief, daily milk and ECM yields were greater at all 4 time points in cows milked $3 \times$ postpartum relative to those milked $1 \times$; however, although milk yield was also greater at wk 3 in cows milked $3 \times$ relative to $2 \times$, and tended to be greater at wk $6(P=0.08)$ and wk $9(P=0.07)$, this effect was not detected for ECM yields, due to lower milk fat and protein contents (data not presented; Phyn et al., 2011). Furthermore, cows milked $1 \times$ postpartum had lower yields of milk and ECM at wk 1, 3, and 6 compared with cows milked $2 \times$. At wk 6 , milking frequency by duration interactions were detected, as cows that remained on $1 \times$ milking for $6 \mathrm{wk}$ had lower milk and ECM yields relative to cows milked $1 \times$ for only 3 wk. Energy-corrected milk yields remained lower at wk 9 in cows previously milked $1 \times$ relative to $2 \times$, but this negative carryover response was not affected by the duration of reduced milking frequency following parturition.

Body condition score at wk 1 postpartum was lower in cows milked $3 \times$ relative to those milked $2 \times$. Cows milked $3 \times$ also had a lower BCS at wk 3 postpartum relative to cows milked $1 \times$, and tended $(P=0.06)$ to have a lower BCS relative to cows milked $2 \times$. By 6 wk, all cows milked $1 \times$ had a greater BCS than cows milked $2 \times$ or $3 \times$; however, a trend $(P=0.07)$ for a milking frequency by duration interaction indicated that differences were greatest for cows milked $1 \times$ for 6 wk postpartum.

Plasma concentrations of glucose, insulin and NEFA are described in Grala et al. (2014) and are presented with IGF-1 and GH in Table 2 for clarity. Plasma concentrations of IGF-1 at wk 3 postpartum were greater in cows milked $1 \times$ relative to $2 \times$ or $3 \times$, but at wk 6 and 9 , cows milked $1 \times$ postpartum only had greater concentrations relative to those milked $3 \times$. At wk 3 postpartum, concentrations of GH were greater in cows milked $3 \times$ relative to those milked $2 \times$. At wk 6 post- partum, a milking frequency by duration interaction indicated that cows milked $3 \times$ for 6 wk continued to have greater $\mathrm{GH}$ concentrations relative to all other treatment groups. Plasma NEFA concentrations at wk 1 were greater in cows milked $3 \times$ compared with those milked $2 \times$. Cows milked $1 \times$ postpartum had lower NEFA at wk 3 and tended $(P=0.06)$ to have lower NEFA at wk 6 relative to cows milked $2 \times$; however, relative to cows milked $3 \times$, they had lower NEFA at wk 1 , 3 , and 6 . Glucose concentrations were reduced in cows milked $3 \times$ at wk 1 relative to cows milked $2 \times$; however, glucose and insulin concentrations were greater at wk 1 and 3 in cows milked $1 \times$. At wk 6 , milking frequency by duration interactions indicated that cows milked $1 \times$ for 6 wk continued to have greater glucose and insulin than cows milked $2 \times$ or $3 \times$. At wk 9, glucose concentrations were still greater and insulin tended $(P=0.09)$ to be greater in cows previously milked $1 \times$ relative to cows previously milked $3 \times$.

\section{Somatotropic Axis Gene Expression}

Liver. Expression values are presented in Table 3. At wk 3 postpartum, expression of total GHR (GHRT) and GHR1A in the liver was lower for cows milked $3 \times$ compared with $2 \times$ or $1 \times$. Expression of $I G F 1$ and IGF acid labile subunit (IGFALS) was lower and IGFbinding protein 3 (IGFBP3) tended $(P=0.06)$ to be lower, whereas insulin receptor (INSR) B transcription was greater in the liver of cows milked $3 \times$ compared with those milked $1 \times$.

Adipose. Expression values are presented in Table 4. At wk 6, GHRT expression in adipose tissue was lower in cows milked $3 \times$ postpartum compared with cows milked $2 \times$ or $1 \times$. Expression of GHR1B also tended $(P=0.06)$ to be lower in cows milked $3 \times$ compared with $2 \times$, and was significantly lower compared with $1 \times$. A milking frequency by duration interaction was detected for IGF1 transcription at wk 6 postpartum. Expression of $I G F 1$ was greater in cows milked $1 \times$ for 6 wk, compared with all other treatments, which did not differ from each other. At wk 9, milking frequency by duration interactions for GHRT and GHR1B expression occurred, such that cows previously milked $3 \times$ for 6 wk, but not $3 \mathrm{wk}$, had lower expression compared with cows milked $2 \times$.

\section{Adipose Lipolytic Gene Expression}

Expression values are presented in Table 5. At wk 3 , no treatment differences existed in the expression of the 3 main lipolytic genes measured [hormone-sensitive lipase (LIPE), perilipin 1 (PLIN1), and patatin-like phospholipase domain-containing protein 2 (PNPLA2)]. 
Table 3. Effect of milking frequency (MF) on hepatic mRNA expression of somatotropic axis genes in cows milked once daily for 3 or 6 wk immediately postpartum $(1 \times$; $=24)$, twice daily for the duration of lactation $(2 \times ; \mathrm{n}=12)$, or 3 times daily for 3 or 6 wk immediately postpartum $(3 \times ; \mathrm{n}=24)$

\begin{tabular}{|c|c|c|c|c|c|c|c|c|c|c|c|c|}
\hline \multirow[b]{2}{*}{ Gene $^{2}$} & \multirow[b]{2}{*}{ Week } & \multicolumn{5}{|c|}{ Treatment } & \multirow[b]{2}{*}{$\mathrm{SED}^{3}$} & \multicolumn{5}{|c|}{$P$-value } \\
\hline & & $1 \times$ for $6 \mathrm{wk}$ & $1 \times$ for $3 w k$ & $2 \times$ & $3 \times$ for $3 \mathrm{wk}$ & $3 \times$ for $6 \mathrm{wk}$ & & $1 \times$ vs. $2 \times$ & $2 \times$ vs. $3 \times$ & $1 \times$ vs. $3 \times$ & Duration & $\begin{array}{l}\text { MF } \times \\
\text { duration }\end{array}$ \\
\hline \multirow[t]{4}{*}{ GHRT } & 1 & & 0.74 & 0.70 & 0.69 & & 0.10 & 0.68 & 0.83 & 0.54 & & \\
\hline & 3 & 0.69 & 0.70 & 0.67 & 0.57 & 0.57 & 0.05 & 0.72 & 0.05 & $<0.01$ & & \\
\hline & 6 & 0.70 & 0.63 & 0.71 & 0.57 & 0.70 & 0.06 & 0.47 & 0.35 & 0.78 & 0.05 & 0.61 \\
\hline & 9 & 0.69 & 0.75 & 0.66 & 0.65 & 0.67 & 0.07 & 0.40 & 0.98 & 0.33 & 0.70 & 0.42 \\
\hline \multirow{4}{*}{ GHR1A } & 1 & & 0.88 & 0.95 & 0.95 & & 0.23 & 0.73 & 0.90 & 0.83 & & \\
\hline & 3 & 1.11 & 1.10 & 1.09 & 0.77 & 0.93 & 0.09 & 0.91 & $<0.05$ & $<0.01$ & & \\
\hline & 6 & 1.08 & 1.04 & 1.14 & 0.99 & 1.12 & 0.09 & 0.36 & 0.42 & 0.92 & 0.31 & 0.53 \\
\hline & 9 & 1.08 & 1.25 & 1.08 & 1.10 & 1.15 & 0.11 & 0.45 & 0.64 & 0.74 & 0.38 & 0.25 \\
\hline \multirow[t]{4}{*}{$I G F 1$} & 1 & & 1.65 & 1.70 & 1.79 & & 0.27 & 0.82 & 0.73 & 0.58 & & \\
\hline & 3 & 1.89 & 1.84 & 1.67 & 1.43 & 1.50 & 0.13 & 0.12 & 0.12 & $<0.001$ & & \\
\hline & 6 & 1.90 & 1.93 & 1.87 & 1.89 & 1.83 & 0.14 & 0.71 & 0.91 & 0.56 & 0.71 & 0.90 \\
\hline & 9 & 1.85 & 2.16 & 1.85 & 1.97 & 1.98 & 0.16 & 0.30 & 0.41 & 0.83 & 0.18 & 0.22 \\
\hline \multirow[t]{4}{*}{ IGFBP3 } & 1 & & 0.27 & 0.24 & 0.21 & & 0.06 & 0.45 & 0.70 & 0.26 & & \\
\hline & 3 & 0.28 & 0.25 & 0.25 & 0.20 & 0.22 & 0.04 & 0.67 & 0.24 & 0.06 & & \\
\hline & 6 & 0.35 & 0.23 & 0.32 & 0.23 & 0.28 & 0.03 & 0.29 & 0.10 & 0.45 & $<0.01$ & 0.22 \\
\hline & 9 & 0.33 & 0.33 & 0.31 & 0.32 & 0.34 & 0.04 & 0.46 & 0.49 & 0.98 & 0.76 & 0.79 \\
\hline \multirow[t]{4}{*}{$I G F A L S$} & 1 & & 0.80 & 0.83 & 0.81 & & 0.12 & 0.73 & 0.90 & 0.64 & & \\
\hline & 3 & 0.88 & 0.89 & 0.83 & 0.61 & 0.77 & 0.08 & 0.49 & 0.11 & $<0.01$ & & \\
\hline & 6 & 0.87 & 0.86 & 0.94 & 0.77 & 0.86 & 0.07 & 0.29 & 0.14 & 0.56 & 0.46 & 0.55 \\
\hline & 9 & 0.87 & 0.96 & 0.82 & 0.93 & 0.93 & 0.07 & 0.20 & 0.14 & 0.76 & 0.40 & 0.47 \\
\hline \multirow{4}{*}{ INSRB } & 1 & & 0.26 & 0.29 & 0.27 & & 0.05 & 0.48 & 0.75 & 0.31 & & \\
\hline & 3 & 0.26 & 0.25 & 0.28 & 0.31 & 0.32 & 0.04 & 0.39 & 0.36 & $<0.05$ & & \\
\hline & 6 & 0.24 & 0.23 & 0.29 & 0.23 & 0.28 & 0.04 & 0.12 & 0.43 & 0.37 & 0.42 & 0.51 \\
\hline & 9 & 0.26 & 0.25 & 0.27 & 0.24 & 0.31 & 0.04 & 0.70 & 0.67 & 0.33 & 0.24 & 0.34 \\
\hline \multicolumn{13}{|c|}{$\begin{array}{l}{ }^{1} \text { Cows milked } 1 \times \text { or } 3 \times \text { were switched to } 2 \times \text { milking after } 3 \text { or } 6 \text { wk on the alternative milking frequency. Data are expressed as logarithmically transformed arbitrary units, norma } \\
\text { ized to the expression of ribosomal protein S15a and tyrosine } 3 \text {-monooxygenase/tryptophan } 5 \text {-monooxygenase activation protein, zeta polypeptide. }\end{array}$} \\
\hline \multicolumn{13}{|c|}{$\begin{array}{l}{ }^{2} G H R T=\text { growth hormone receptor total; GHR } 1 A=\text { growth hormone receptor } 1 \mathrm{a} ; I G F 1=\text { insulin-like growth factor } 1 ; I G F B P 3=\text { insulin-like growth factor-binding protein } \\
I G F A L S=\text { insulin-like growth factor acid labile subunit; INSRB = insulin receptor b. } \\
{ }^{3} \text { Standard error of the difference. }\end{array}$} \\
\hline
\end{tabular}




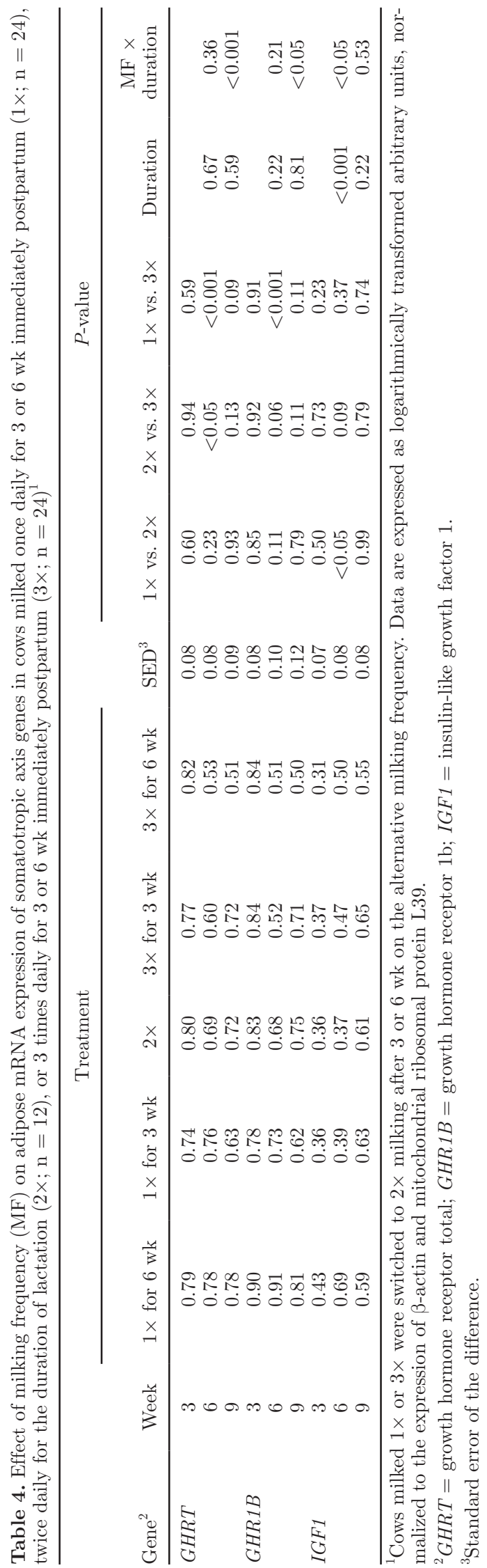

However, expression of angiopoietin-like 4 (ANGPTL4) was lower in cows milked $1 \times$ compared with cows milked $2 \times$ and tended $(P=0.09)$ to be lower compared with cows milked $3 \times$.

At wk 6, expression of LIPE and PLIN1 was greater in all cows milked $1 \times$ compared with all cows milked $3 \times$. In addition, all cows milked $1 \times$ tended $(P=0.07)$ to have greater LIPE expression than cows milked $2 \times$. A milking frequency by duration interaction was detected for PNPLA2 expression at wk 6 . Cows milked $1 \times$ for 6 wk had greater PNPLA2 expression compared with cows milked $2 \times$ or $3 \times$; however, cows milked $1 \times$ for 3 wk only had greater PNPLA2 expression compared with cows milked $3 \times$ for $6 \mathrm{wk}$. Also at wk 6 postpartum, FA-binding protein $4(F A B P 4)$ was downregulated in cows milked $3 \times$ compared with cows milked $2 \times$ or $1 \times$.

At wk 9 , all cows previously milked $3 \times$ had lower expression of LIPE, PLIN1, PNPLA2, and ANGPTL4 compared with cows milked $2 \times$. In addition, cows previously milked $3 \times$ had lower expression of $L I P E$ and PNPLA2, and tended $(P=0.07)$ to have lower PLIN1 expression compared with cows milked $1 \times$. A trend $(P$ $=0.06$ ) existed for a milking frequency by duration interaction for $F A B P 4$ expression, such that cows milked $3 \times$ for 6 wk had lower expression compared with cows milked $1 \times$ for 6 wk or $2 \times$. Additionally, all cows previously milked $1 \times$ tended $(P=0.09)$ to have lower ANGPTL4 expression compared with cows milked $2 \times$.

\section{Adipose $\beta$-Oxidation Gene Expression}

Expression values are presented in Table 5. At wk 6 postpartum, milking frequency by duration interactions were detected for acyl-CoA synthetase long-chain family member 1 (ACSL1) and carnitine palmitoyltransferase 2 (CPT2). Expression of ACSL1 was greater in cows milked $1 \times$ for $6 \mathrm{wk}$, and lower in cows milked $3 \times$ for 6 wk, compared with the other treatments, which did not differ from each other. Expression of CPT2 was greater in cows milked $1 \times$ for 6 wk than all other treatments, which did not differ from each other.

At wk 9, expression of ACSL1 was lower in all cows previously milked $3 \times$ compared with $1 \times$. A milking frequency by duration interaction existed for CPT2 and expression at wk 9 was greater in cows milked $1 \times$ for $6 \mathrm{wk}$, and lower in cows milked $3 \times$ for $6 \mathrm{wk}$, compared with other treatments, which did not differ from each other.

\section{Adipose Lipogenic and Reesterification Gene Expression}

Expression values are presented in Table 6. At wk 3, the transcription of genes involved with lipogenesis and 
Table 5. Effect of milking frequency (MF) on adipose mRNA expression of lipolysis and $\beta$-oxidation genes in cows milked once daily for 3 or 6 wk immediately postpartum $(1 \times$; $\mathrm{n}=24)$, twice daily for the duration of lactation $(2 \times ; \mathrm{n}=12)$, or 3 times daily for 3 or 6 wk immediately postpartum $(3 \times ; \mathrm{n}=24)^{1}$

\begin{tabular}{|c|c|c|c|c|c|c|c|c|c|c|c|c|}
\hline \multirow[b]{2}{*}{ Gene $^{2}$} & \multirow[b]{2}{*}{ Week } & \multicolumn{5}{|c|}{ Treatment } & \multirow[b]{2}{*}{$\mathrm{SED}^{3}$} & \multicolumn{5}{|c|}{$P$-value } \\
\hline & & $1 \times$ for $6 \mathrm{wk}$ & $1 \times$ for $3 \mathrm{wk}$ & $2 \times$ & $3 \times$ for $3 \mathrm{wk}$ & $3 \times 6 \mathrm{wk}$ & & $1 \times$ vs. $2 \times$ & $2 \times$ vs. $3 \times$ & $1 \times$ vs. $3 \times$ & Duration & $\begin{array}{c}\mathrm{MF} \times \\
\text { duration }\end{array}$ \\
\hline \multirow[t]{3}{*}{ LIPE } & 3 & 2.19 & 2.10 & 2.20 & 2.10 & 2.13 & 0.13 & 0.61 & 0.41 & 0.70 & & \\
\hline & 6 & 2.16 & 2.11 & 1.81 & 1.65 & 1.63 & 0.21 & 0.07 & 0.34 & $<0.001$ & 0.93 & 0.83 \\
\hline & 9 & 1.89 & 1.78 & 1.88 & 1.65 & 1.45 & 0.18 & 0.78 & $<0.05$ & $<0.05$ & 0.68 & 0.23 \\
\hline \multirow{3}{*}{ PLIN1 } & 3 & 1.60 & 1.44 & 1.65 & 1.54 & 1.61 & 0.12 & 0.20 & 0.45 & 0.54 & & \\
\hline & 6 & 1.48 & 1.44 & 1.31 & 1.16 & 1.16 & 0.18 & 0.33 & 0.31 & $<0.05$ & 0.87 & 0.87 \\
\hline & 9 & 1.16 & 1.16 & 1.33 & 1.09 & 0.85 & 0.16 & 0.21 & $<0.01$ & 0.07 & 0.29 & 0.28 \\
\hline \multirow[t]{3}{*}{ PNPLA2 } & 3 & 1.28 & 1.19 & 1.19 & 1.11 & 1.18 & 0.11 & 0.54 & 0.69 & 0.22 & & \\
\hline & 6 & 1.37 & 1.13 & 1.00 & 0.96 & 0.78 & 0.14 & $<0.05$ & 0.23 & $<0.001$ & 0.73 & $<0.05$ \\
\hline & 9 & 1.14 & 1.08 & 1.13 & 0.93 & 0.72 & 0.15 & 0.91 & $<0.05$ & $<0.01$ & 0.46 & 0.20 \\
\hline \multirow[t]{3}{*}{ ANGPTL4 } & 3 & 1.17 & 1.02 & 1.31 & 1.22 & 1.22 & 0.10 & $<0.05$ & 0.28 & 0.09 & & \\
\hline & 6 & 1.16 & 1.23 & 1.19 & 1.13 & 1.00 & 0.14 & 0.97 & 0.26 & 0.15 & 0.31 & 0.77 \\
\hline & 9 & 0.86 & 0.89 & 1.09 & 0.92 & 0.66 & 0.15 & 0.09 & $<0.05$ & 0.35 & 0.18 & 0.29 \\
\hline \multirow{3}{*}{$F A B P_{4}$} & 3 & 1.30 & 1.21 & 1.46 & 1.32 & 1.42 & 0.14 & 0.09 & 0.46 & 0.25 & & \\
\hline & 6 & 1.33 & 1.24 & 1.16 & 0.93 & 0.85 & 0.15 & 0.34 & $<0.05$ & $<0.001$ & 0.93 & 0.44 \\
\hline & 9 & 1.10 & 1.00 & 1.10 & 1.01 & 0.79 & 0.12 & 0.71 & $<0.05$ & 0.05 & 0.47 & 0.06 \\
\hline \multirow[t]{3}{*}{$A C S L 1$} & 3 & 0.65 & 0.71 & 0.61 & 0.65 & 0.69 & 0.10 & 0.45 & 0.49 & 0.94 & & \\
\hline & 6 & 1.02 & 0.68 & 0.62 & 0.64 & 0.39 & 0.12 & $<0.05$ & 0.22 & $<0.001$ & 0.53 & $<0.001$ \\
\hline & 9 & 0.90 & 0.86 & 0.74 & 0.76 & 0.49 & 0.14 & 0.22 & 0.27 & $<0.01$ & 0.24 & 0.12 \\
\hline \multirow{3}{*}{ СPT2 } & 3 & 0.29 & 0.24 & 0.23 & 0.25 & 0.18 & 0.05 & 0.39 & 0.83 & 0.20 & & \\
\hline & 6 & 0.49 & 0.26 & 0.24 & 0.26 & 0.24 & 0.06 & $<0.01$ & 0.89 & $<0.01$ & $<0.01$ & $<0.01$ \\
\hline & 9 & 0.43 & 0.33 & 0.31 & 0.34 & 0.23 & 0.04 & 0.05 & 0.45 & $<0.01$ & 0.86 & $<0.01$ \\
\hline
\end{tabular}

${ }^{1}$ Cows milked $1 \times$ or $3 \times$ were switched to $2 \times$ milking after 3 or 6 wk on the alternative milking frequency. Data are expressed as logarithmically transformed arbitrary units, normalized to the expression of $\beta$-actin and mitochondrial ribosomal protein L39.

을 ${ }^{2} L I P E=$ hormone-sensitive lipase; PLIN1 = perilipin; PNPLA2 = patatin-like phospholipase domain containing 2; $A N G P T L 4=$ angiopoietin-like $4 ; F A B P 4=$ FA-binding protein

O $4 ; A C S L 1=$ acyl-CoA synthetase long-chain family member 1; CPT2 = carnitine palmitoyltransferase 2.

$\stackrel{\$}{\equiv}$ Standard error of the difference. 
Table 6. Effect of milking frequency (MF) on adipose mRNA expression of lipogenic genes in cows milked once daily for 3 or 6 wk immediately postpartum (1×; $\mathrm{n}=24)$, twice daily for the duration of lactation $(2 \times ; \mathrm{n}=12)$, or 3 times daily for 3 or 6 wk immediately postpartum $(3 \times ; \mathrm{n}=24)$

\begin{tabular}{|c|c|c|c|c|c|c|c|c|c|c|c|c|}
\hline \multirow[b]{2}{*}{ Gene $^{2}$} & \multirow[b]{2}{*}{ Week } & \multicolumn{5}{|c|}{ Treatment } & \multirow[b]{2}{*}{$\mathrm{SED}^{3}$} & \multicolumn{5}{|c|}{$P$-value } \\
\hline & & $1 \times$ for $6 \mathrm{wk}$ & $1 \times$ for $3 \mathrm{wk}$ & $2 \times$ & $3 \times$ for $3 \mathrm{wk}$ & $3 \times$ for $6 \mathrm{wk}$ & & $1 \times$ vs. $2 \times$ & $2 \times$ vs. $3 \times$ & $1 \times$ vs. $3 \times$ & Duration & $\begin{array}{c}\text { MF } \times \\
\text { duration }\end{array}$ \\
\hline \multirow[t]{3}{*}{$A C A C A$} & 3 & 0.90 & 0.93 & 0.57 & 0.54 & 0.56 & 0.13 & $<0.01$ & 0.84 & $<0.001$ & & \\
\hline & 6 & 1.37 & 0.84 & 0.57 & 0.67 & 0.46 & 0.13 & $<0.001$ & 0.87 & $<0.001$ & 0.07 & $<0.0001$ \\
\hline & 9 & 1.32 & 1.23 & 1.02 & 0.96 & 0.70 & 0.16 & 0.06 & 0.14 & $<0.001$ & 0.44 & 0.13 \\
\hline \multirow{3}{*}{ ELOVL5 } & 3 & 0.63 & 0.73 & 0.52 & 0.47 & 0.48 & 0.09 & $<0.05$ & 0.59 & $<0.01$ & & \\
\hline & 6 & 1.02 & 0.66 & 0.49 & 0.50 & 0.52 & 0.09 & $<0.001$ & 0.73 & $<0.001$ & $<0.01$ & $<0.05$ \\
\hline & 9 & 0.94 & 0.88 & 0.68 & 0.79 & 0.60 & 0.11 & $<0.05$ & 0.94 & $<0.01$ & 0.40 & 0.09 \\
\hline \multirow[t]{3}{*}{$F A S N$} & 3 & 1.46 & 1.52 & 0.64 & 0.78 & 0.63 & 0.19 & $<0.001$ & 0.73 & $<0.001$ & & \\
\hline & 6 & 2.23 & 1.50 & 1.07 & 1.15 & 1.02 & 0.19 & $<0.001$ & 0.95 & $<0.001$ & $<0.05$ & $<0.01$ \\
\hline & 9 & 2.10 & 2.02 & 1.86 & 1.83 & 1.48 & 0.19 & 0.21 & 0.15 & $<0.01$ & 0.29 & 0.10 \\
\hline \multirow[t]{3}{*}{ GPAM } & 3 & 1.25 & 1.13 & 0.78 & 0.84 & 1.04 & 0.15 & $<0.01$ & 0.20 & $<0.05$ & & \\
\hline & 6 & 1.65 & 1.01 & 0.81 & 0.73 & 0.74 & 0.15 & $<0.001$ & 0.57 & $<0.001$ & $<0.01$ & $<0.01$ \\
\hline & 9 & 1.45 & 1.26 & 1.21 & 1.10 & 0.82 & 0.19 & 0.33 & 0.10 & $<0.01$ & 0.72 & 0.08 \\
\hline \multirow[t]{3}{*}{$G P D 1$} & 3 & 1.30 & 1.22 & 0.90 & 0.94 & 0.91 & 0.15 & $<0.01$ & 0.86 & $<0.01$ & & \\
\hline & 6 & 1.67 & 1.18 & 1.09 & 1.03 & 0.73 & 0.14 & $<0.01$ & 0.07 & $<0.001$ & 0.29 & $<0.0001$ \\
\hline & 9 & 1.55 & 1.37 & 1.44 & 1.36 & 1.06 & 0.15 & 0.82 & 0.06 & $<0.05$ & 0.57 & $<0.05$ \\
\hline \multirow[t]{3}{*}{$L P L$} & 3 & 0.81 & 0.86 & 0.45 & 0.49 & 0.35 & 0.12 & $<0.001$ & 0.75 & $<0.001$ & & \\
\hline & 6 & 1.17 & 0.92 & 0.55 & 0.50 & 0.51 & 0.11 & $<0.001$ & 0.67 & $<0.001$ & 0.10 & 0.14 \\
\hline & 9 & 1.10 & 1.00 & 0.92 & 0.84 & 0.68 & 0.14 & 0.26 & 0.15 & $<0.01$ & 0.73 & 0.19 \\
\hline \multirow[t]{3}{*}{$O X C T 1$} & 3 & 0.55 & 0.55 & 0.44 & 0.43 & 0.35 & 0.06 & $<0.05$ & 0.31 & $<0.001$ & & \\
\hline & 6 & 0.65 & 0.45 & 0.37 & 0.42 & 0.33 & 0.07 & $<0.01$ & 0.99 & $<0.001$ & 0.24 & $<0.01$ \\
\hline & 9 & 0.77 & 0.58 & 0.60 & 0.59 & 0.38 & 0.08 & 0.26 & 0.07 & $<0.001$ & 0.80 & $<0.001$ \\
\hline \multirow[t]{3}{*}{ PCK1 } & 3 & 1.81 & 1.63 & 1.65 & 1.77 & 1.55 & 0.24 & 0.69 & 0.97 & 0.67 & & \\
\hline & 6 & 2.23 & 1.35 & 1.61 & 1.60 & 1.21 & 0.26 & 0.43 & 0.31 & $<0.05$ & 0.16 & $<0.01$ \\
\hline & 9 & 1.61 & 1.26 & 1.50 & 1.25 & 1.05 & 0.26 & 0.82 & 0.10 & 0.09 & 0.71 & 0.14 \\
\hline \multirow[t]{3}{*}{$P P A R G$} & 3 & 1.24 & 1.17 & 1.19 & 1.16 & 1.22 & 0.10 & 0.84 & 0.95 & 0.873 & & \\
\hline & 6 & 1.26 & 1.11 & 0.96 & 0.81 & 0.89 & 0.13 & $<0.05$ & 0.36 & $<0.001$ & 0.22 & 0.70 \\
\hline & 9 & 1.12 & 1.01 & 1.02 & 0.93 & 0.85 & 0.13 & 0.65 & 0.25 & 0.06 & 0.88 & 0.30 \\
\hline \multirow[t]{3}{*}{$S C D$} & 3 & 1.11 & 1.21 & 0.80 & 0.61 & 0.70 & 0.19 & $<0.05$ & 0.42 & $<0.001$ & & \\
\hline & 6 & 1.74 & 1.15 & 0.86 & 0.87 & 0.66 & 0.18 & $<0.001$ & 0.48 & $<0.001$ & 0.13 & $<0.01$ \\
\hline & 9 & 1.66 & 1.65 & 1.41 & 1.53 & 1.04 & 0.18 & 0.11 & 0.26 & $<0.01$ & 0.07 & 0.05 \\
\hline \multirow[t]{3}{*}{ THRSP } & 3 & 1.45 & 1.53 & 1.06 & 1.10 & 0.99 & 0.19 & $<0.05$ & 0.91 & $<0.01$ & & \\
\hline & 6 & 2.03 & 1.54 & 1.04 & 1.10 & 0.85 & 0.20 & $<0.001$ & 0.65 & $<0.001$ & 0.39 & $<0.05$ \\
\hline & 9 & 1.91 & 1.85 & 1.65 & 1.66 & 1.14 & 0.21 & 0.21 & 0.11 & $<0.01$ & 0.12 & 0.06 \\
\hline
\end{tabular}

${ }^{1}$ Cows milked $1 \times$ or $3 \times$ were switched to $2 \times$ milking after 3 or $6 \mathrm{wk}$ on the alternative milking frequency. Data are expressed as logarithmically transformed arbitrary units, normalized to the expression of $\beta$-actin and mitochondrial ribosomal protein L39.

${ }^{2} A C A C A=$ acetyl-CoA carboxylase $\alpha ; E L O V L 5=$ ELOVL family member 5, elongation of long-chain FA; FASN = FA synthase; GPAM = glycerol-3-phosphate acyltransferase, mitochondrial; GPD1 = glycerol-3-phosphate dehydrogenase 1 (soluble); $L P L=$ lipoprotein lipase; $O X C T 1=3$-oxoacid CoA transferase $1 ; P C K 1=$ phosphoenolpyruvate carboxykinase 1 (soluble); PPARG = peroxisome proliferator-activated receptor gamma; $S C D=$ stearoyl-CoA desaturase; THRSP = thyroid hormone responsive (SPOT14 homolog, rat).

${ }^{3}$ Standard error of the difference. 
reesterification [lipoprotein lipase $(L P L)$, acetyl-CoA carboxylase $\alpha(A C A C A)$, FA synthase $(F A S N)$, stearoyl-CoA desaturase $(S C D)$, elongation of long-chain FA member 5 (ELOVL5), glycerol-3-phosphate acyltransferase $(G P A M)$, glycerol-3-phosphate dehydrogenase 1 (GPD1), 3-oxoacid CoA transferase 1 (OXCT1), and thyroid hormone responsive $(T H R S P)]$ was greater in cows milked $1 \times$ compared with $2 \times$ or $3 \times$.

At wk 6 , there were many milking frequency by duration interactions. Cows milked $1 \times$ for 6 wk had greater expression of ACACA; ELOVL5; FASN; GPAM; GPD1; OXCT1; phosphoenolpyruvate carboxykinase 1, soluble (PCK1), SCD; and THRSP compared with all other treatments. Additionally, at wk 6 , cows milked $1 \times$ for 3 wk had greater expression of $A C A C A, F A S N$, and THRSP than cows milked $2 \times$ and greater $A C A C A$, FASN, SCD, and THRSP expression than cows milked $3 \times$ for 6 wk. Furthermore, expression of GPD1 was lower in cows milked $3 \times$ for 6 wk compared with all other treatments. At wk 6, there were no interactions between milking frequency and duration for $L P L$ or $P P A R G$, and expression of $L P L$ and $P P A R G$ was greater in all cows milked $1 \times$ relative to $2 \times$.

At wk 9, greater $A C A C A, F A S N$, and $L P L$ expression was detected, and trends $(P=0.09$ and $P=0.06$, respectively) for greater $P C K 1$ and $P P A R G$ expression were detected in all cows previously milked $1 \times$ compared with $3 \times$. Cows previously milked $1 \times$ also tended $(P=0.06)$ to have greater $A C A C A$ expression relative to those milked $2 \times$ from calving. Milking frequency by duration interactions existed for GPD1, OXCT1, and $S C D$, and trends $(P=0.09, P=0.08$, and $P=$ 0.06 , respectively) for interactions existed for $E L O V L 5$, GPAM, and THRSP. Cows previously milked $3 \times$ for 6 wk had lower expression of GPD1, SCD, GPAM, and THRSP compared with all other treatments. Expression of OXCT1 was greater in cows previously milked $1 \times$ for $6 \mathrm{wk}$, and lower in cows previously milked $3 \times$ for $6 \mathrm{wk}$, compared with all other treatments. Cows previously milked $1 \times$ for 6 wk had greater expression of ELOVL 5 than cows previously milked $2 \times$ or $3 \times$ for 6 wk; however, cows milked $1 \times$ for 3 wk postpartum only had greater ELOVL5 expression compared with cows milked $3 \times$ for $6 \mathrm{wk}$.

\section{DISCUSSION}

Differences in the plasma measurements and transcription of genes involved in the somatotropic axis and lipid metabolism indicate that increased milking frequency postpartum increases energy demands to sustain galactopoiesis, whereas these adaptations are required to a lesser degree in cows milked $1 \times$. The increase in mammary energy output in cows milked $3 \times$ requires carefully coordinated homeorhetic adjustments across different body tissues.

\section{Greater Somatotropic Axis Uncoupling Occurred in Cows Milked 3x}

Reduced hepatic transcription of GHR1A at wk 3 postpartum in cows milked $3 \times$ is indicative of greater somatotropic axis uncoupling compared with cows milked less frequently. Reduced GHR1A would decrease the sensitivity of the liver to GH signaling, therefore modulating the transcription of GHR1A, IGF1, IGFALS, and IGFBP3 (Jiang et al., 2007; Vijayakumar et al., 2010). This expression modulation explains the reduced transcription of these genes in the liver of cows milked $3 \times$. The increased plasma $\mathrm{GH}$ and decreased IGF-1 concentrations in cows milked $3 \times$ support the gene transcription measures and indicate that the somatotropic axis of $3 \times$ cows was more uncoupled, particularly compared with $1 \times$ cows. Although plasma GH was only measured weekly and GH is secreted in a pulsatile fashion, the GH changes in the current study support the gene expression results and plasma IGF-1 changes, consistent with previous studies using weekly plasma GH measurements in this manner (Kobayashi et al., 1999; Grala et al., 2011).

It has been reported that insulin is involved in stimulating GHR1A transcription, and, hence, recoupling of the somatotropic axis (Butler et al., 2003). In the present study, insulin concentrations and expression of GHR1A, IGF1, and IGFALS in the liver were similar at wk 6 postpartum between cows milked $3 \times$ and those milked $2 \times$. By wk 9, no treatment effects existed, indicating that the somatotropic axis was recoupled and the effect of postpartum milking frequency was transient. The somatotropic axis is also altered by nutritional status (McGuire et al., 1995), and due to the lack of individual feed intake data in the current study, differences in nutrition may have contributed to the uncoupling despite the generous pasture allowance and supplementary feed provided.

Cows milked $3 \times$ had greater BCS loss during the first week postpartum than cows milked $2 \times$ (Phyn et al., 2011), indicating that the adipose tissue of these cows was initially responsive to the effects of $\mathrm{GH}$ and more body fat was mobilized to support the mammary gland's greater energy requirements for milk production. This was confirmed by the increase in NEFA concentrations at this time. These effects, however, were short lived, as NEFA concentrations did not differ between cows milked $3 \times$ and $2 \times$ thereafter and BCS converged from wk 4 onwards (Phyn et al. 2011), indicating that in cows milked $3 \times$, mobilization of subcutaneous fat stores was not greater after wk-1 postpartum. This re- 
sult is unexpected considering that cows milked $3 \times$ had elevated plasma $\mathrm{GH}$ concentrations at wk 3 postpartum, and those animals that remained on $3 \times$ milking had greater GH concentrations at wk 6 . However, by wk 6 postpartum, adipose tissue transcription of $G H R T$ was reduced and the main variant in adipose, GHR1B, tended to be reduced in cows milked $3 \times$ compared with $2 \times$, potentially indicating some resistance to $\mathrm{GH}$ signaling in response to $3 \times$ daily milking.

Reduced GHRT expression after 6 wk of $3 \times$ milking may result from negative feedback from reduced adipose stores, as downregulation of GHR expression in adipose tissue would limit further efflux of FFA, thereby preserving lipid reserves and preventing excessive body fat mobilization during early lactation. Indeed, NEFA concentrations at wk 3 and 6 were similar between cows milked $2 \times$ and $3 \times$, indicating that net export of FA from adipose reserves was also similar and, therefore, in cows milked $3 \times$, the export of FA was not greater after wk-1 postpartum. In adipose-specific GHR KO mice models, adiposity was increased (List et al., 2013), supporting the hypothesis that reduced $G H R$ mRNA expression would minimize body fat mobilization. The GHR abundance in adipose tissue after $2 \mathrm{wk}$ of negative energy balance has been studied in cows with no effect on GHR mRNA, but reductions in GHR protein expression have been reported (Rhoads et al., 2007). This indicates that GHR expression is altered by changes to energy balance and the differences in $G H R$ mRNA expression between the study of Rhoads et al. (2007) and the current study may be due to the length or severity of the negative energy balance.

Furthermore, the decreased adipose transcription of GHR at wk 6 and lack of continued BCS loss in cows milked $3 \times$ relative to $2 \times$ in the current study may be a result of the pasture-based farming system and the genetics of the New Zealand strain of Holstein-Friesian cow. Milking these grazing cows $3 \times$ for 6 wk postpartum did not increase milk production beyond what was achieved in cows milked $3 \times$ for only 3 wk (Phyn et al., 2011), indicating that a production ceiling was reached in animals genetically selected for and managed in a pasture-based system where excessive body fat mobilization is detrimental to maintain an annual, seasonally concentrated breeding cycle.

\section{Lipolysis and Lipogenesis in Cows Milked 3x}

Increased adipose tissue lipolysis and FA export in cows milked $3 \times$ relative to $2 \times$ was not evident from gene transcription measured at wk 3 and 6 , despite these cows having an increased milk yield and lower BCS during the first $3 \mathrm{wk}$ of lactation (Phyn et al., 2011). This finding may simply reflect that the greatest differences in BCS loss and plasma NEFA concentrations between cows milked $3 \times$ and $2 \times$ occurred at wk 1 postpartum when lipolytic gene expression was not measured. Nevertheless, authors measuring actual rates of lipolysis in bovine adipose tissue (McNamara and Hillers, 1986; Sumner and McNamara, 2007; Rocco and McNamara, 2013) have not reported high concordance with mRNA expression, which they suggest is due to posttranslational control of lipolysis. Additionally, gene expression studies over the transition period indicate only minor lipolytic gene expression changes during early lactation in combination with increased NEFA concentrations (Khan et al., 2013), consistent with the results presented here, indicating that mRNA abundance may not be a good indicator of lipolysis. It is also possible that the lack of an increase in lipolytic mRNA expression may be due to the depot of adipose tissue biopsied, as the subcutaneous depot may be less responsive to GH signaling than omental depots (Erman et al., 2011).

Instead, gene expression data in the current study indicates that cows milked $3 \times$ for 6 wk may have increased nutrient availability for milk production by downregulating genes involved in de novo FA synthesis and reesterification. This downregulation was maintained at wk 9, after cows had been switched to $2 \times$ milking for $3 \mathrm{wk}$, indicating delayed adaptation to the new regimen. Lipogenic gene transcription decreases during early lactation (Janovick et al., 2009; Khan et al., 2013), indicating that milk production limits adipose lipogenesis. Additionally, all cows previously milked $3 \times$ had similar plasma concentrations of NEFA at wk 3,6 , and 9 to cows milked $2 \times$, but had reduced lipolytic gene transcription at wk 9 . This result may indicate inhibition of lipolysis in cows with less tissue reserves to mobilize, or a reduction in lipolysis because of the reduced energy required for milk production after cows are switched to $2 \times$ milking. Further work is required to explore the inhibition of lipolysis at this time. In general, however, cows milked $3 \times$ were able to partition more energy for milk production through reducing lipogenic gene transcription in adipose tissue.

\section{Lipogenesis Is Greater in Cows Milked 1x at 3 wk Postpartum}

All 10 lipogenic and reesterification genes measured in adipose tissue were greater in cows milked $1 \times$, compared with cows milked $2 \times$ or $3 \times$, both during and after the period of $1 \times$ milking. Increased lipogenesis and reesterification relative to similar rates of lipolysis would encourage the formation of adipose stores in cows milked $1 \times$. Lipolytic gene expression was not altered at 3 wk but plasma NEFA concentrations were 
reduced in cows milked $1 \times$, indicating reduced lipolysis, or increased reesterification of FA compared with cows milked $2 \times$ and $3 \times$. In the current study, transcription of PPARG was also greater at $6 \mathrm{wk}$ in all cows milked $1 \times$ postpartum, and adipose $P C K 1$ transcription was greater in cows milked $1 \times$ for 6 wk compared with cows milked $1 \times$ for 3 wk or $2 \times$, indicating an increase in glycerol-3-phosphate production for FA esterification into TAG. This process protects the animal against excess FA and subsequent insulin resistance (Beale et al., 2007). Increased transcription of $P P A R G$ at this time may have enhanced the transcription of $P C K 1$ through the PPARG-binding site in the promoter region of PCK1 (Millward et al., 2010).

Consistent with an effect of $1 \times$ milking on increasing adipose storage of TAG, NEFA concentrations in plasma were lower and insulin concentrations greater in cows milked $1 \times$ compared with $2 \times$ or $3 \times$. An increased capability to store TAG may be a priority pathway in cows milked $1 \times$ in response to their lower energy requirements for milk production by the mammary gland.

\section{Lipolysis and FA Oxidation Are Greater in Cows Milked 1x}

Interestingly, at wk 6 , all cows currently or previously on $1 \times$ milking had greater basal and stimulated lipolytic gene transcription relative to cows milked $3 \times$. This effect indicates that cows milked $1 \times$, once switched to $2 \times$, may increase lipolytic gene expression to cope with increased energy demand from the greater milk production (McNamara, 1991), or to regulate adiposity (Kennedy, 1953). Alternatively, the enhanced lipolysis and reesterification may be important in the fine-tune regulation of metabolic demands (Kalderon et al., 2000).

Lipolysis of TAG results in reesterification of part of the FA released, back into TAG (Hammond and Johnston, 1987; Wang et al., 2003), resulting in a futile TAG/FA cycle. This cycle requires ATP (Baldwin, 1970), which can be supplied by glucose oxidation (Flatt, 1970), de novo lipogenesis from glucose, or FA oxidation (Flachs et al., 2013). However, in lactating ruminants, glucose is preferentially used for milk production (Aschenbach et al., 2010); therefore, energy is not likely supplied from glucose. Transcription of ACSL1 and CPT2 were both greater at wk 6 in cows still being milked $1 \times$, indicating increased FA oxidation compared with cows that were being milked $2 \times$ or $3 \times$ at that time point. Although white adipose tissue is not traditionally thought to have high oxidative capacity, recent research has identified that the activation of lipolysis associates with stimulation of FA oxidation (Cho et al., 2009). It is possible that the metabolic flexibility of adipocytes is increased in cows milked $1 \times$ for 6 wk due to increased futile cycling possible through increased oxidation. This, however, is not a mechanism desired in a dairy cow, as energy is being utilized in a futile manner, rather than for milk production, which may reduce overall animal efficiency.

\section{CONCLUSIONS}

Temporary alterations to milking frequency immediately postpartum have immediate and short-term carryover effects on the metabolism of dairy cows. Cows milked $1 \times$ had greater rates of lipogenesis, reesterification, lipolysis, and FA oxidation during $1 \times$ milking, and greater lipogenesis and FA oxidation after treatments. Cows milked $3 \times$ had greater somatotropic axis uncoupling in the liver during treatment and cows milked $3 \times$ for 6 wk had reduced GHR mRNA expression in adipose tissue at $6 \mathrm{wk}$ postpartum. Changes to milking frequency in early lactation altered metabolism during and after the change as the transcription of key genes was modified to support nutrient supply for milk production as well as maintaining adipose stores.

\section{ACKNOWLEDGMENTS}

The authors acknowledge the statistical expertise of Barbara Dow (DairyNZ, Hamilton New Zealand) and all the help afforded by DairyNZ Lye Farm staff, especially Stuart Morgan for tissue biopsy sampling and animal measurements. This study was funded by New Zealand dairy farmers through DairyNZ Inc. and by the New Zealand Ministry of Business, Innovation and Employment (Wellington, New Zealand).

\section{REFERENCES}

Altschul, S. F., W. Gish, W. Miller, E. W. Myers, and D. J. Lipman. 1990. Basic local alignment search tool. J. Mol. Biol. 215:403-410. Andersen, C. L., J. L. Jensen, and T. F. Ørntoft. 2004a. Normalization of real-time quantitative reverse transcription-PCR data: A model-based variance estimation approach to identify genes suited for normalization, applied to bladder and colon cancer data sets. Cancer Res. 64:5245-5250.

Andersen, J. B., N. C. Friggens, T. Larsen, M. Vestergaard, and K. L. Ingvartsen. 2004b. Effect of energy density in the diet and milking frequency on plasma metabolites and hormones in early lactation dairy cows. J. Vet. Med. A Physiol. Pathol. Clin. Med. 51:52-57.

Aschenbach, J. R., N. B. Kristensen, S. S. Donkin, H. M. Hammon, and G. B. Penner. 2010. Gluconeogenesis in dairy cows: The secret of making sweet milk from sour dough. IUBMB Life 62:869-877.

Baldwin, R. L. 1970. Metabolic functions affecting the contribution of adipose tissue to total energy expenditure. Fed. Proc. 29:12771283.

Bauman, D. E., and B. W. Currie. 1980. Partitioning of nutrients during pregnancy and lactation: A review of mechanisms involving homeostasis and homeorhesis. J. Dairy Sci. 63:1514-1529.

Beale, E. G., B. J. Harvey, and C. Forest. 2007. PCK1 and PCK2 as candidate diabetes and obesity genes. Cell Biochem. Biophys. 48:89-95. 
Bell, A. W., and D. E. Bauman. 1997. Adaptations of glucose metabolism during pregnancy and lactation. J. Mammary Gland Biol. Neoplasia 2:265-278.

Butler, S. T., A. L. Marr, S. H. Pelton, R. P. Radcliff, and M. C. Lucy 2003. Insulin restores GH responsiveness during lactation-induced negative energy balance in dairy cattle: Effects on expression of IGF-I and GH receptor 1A. J. Endocrinol. 176:205-217.

Chagas, L. M., P. J. S. Gore, S. Meier, K. A. Macdonald, and G. A. Verkerk. 2007. Effect of monopropylene glycol on luteinizing hormone, metabolites, and postpartum anovulatory intervals in primiparous dairy cows. J. Dairy Sci. 90:1168-1175. http://dx.doi. org/10.3168/jds.S0022-0302(07)71603-X.

Chagas, L. M., M. C. Lucy, P. J. Back, D. Blache, J. M. Lee, P. J. S. Gore, A. J. Sheahan, and J. R. Roche. 2009. Insulin resistance in divergent strains of Holstein-Friesian dairy cows offered fresh pasture and increasing amounts of concentrate in early lactation. J. Dairy Sci. 92:216-222.

Cho, S. Y., P. J. Park, E. S. Shin, J. H. Lee, H. K. Chang, and T. R Lee. 2009. Proteomic analysis of mitochondrial proteins of basal and lipolytically (isoproterenol and $\mathrm{TNF} \alpha$ )-stimulated adipocytes. J. Cell. Biochem. 106:257-266.

Downing, J. A., J. Joss, P. Connell, and R. J. Scaramuzzi. 1995. Ovulation rate and the concentrations of gonadotrophic and metabolic hormones in ewes fed lupin grain. J. Reprod. Fertil. 103:137-145.

Erman, A., A. Veilleux, A. Tchernof, and C. G. Goodyer. 2011. Human growth hormone receptor (GHR) expression in obesity: I. GHR mRNA expression in omental and subcutaneous adipose tissues of obese women. Int. J. Obes. (Lond.) 35:1511-1519. http://dx.doi. org/10.1038/ijo.2011.23.

Eslamizad, M., M. Dehghan-Banadaky, K. Rezayazdi, and M. MoradiShahrbabak. 2010. Effects of 6 times daily milking during early versus full lactation of Holstein cows on milk production and blood metabolites. J. Dairy Sci. 93:4054-4061.

Flachs, P., M. Rossmeisl, O. Kuda, and J. Kopecky. 2013. Stimulation of mitochondrial oxidative capacity in white fat independent of UCP1: A key to lean phenotype. Biochim. Biophys. Acta 1831:986-1003.

Flatt, J. P. 1970. Conversion of carbohydrate to fat in adipose tissue: An energy-yielding and, therefore, self-limiting process. J. Lipid Res. 11:131-143.

Gluckman, P. D., J. J. Johnson-Barrett, J. H. Butler, B. W. Edgar, and T. R. Gunn. 1983. Studies of insulin-like growth factor -I and -II by specific radioligand assays in umbilical cord blood. Clin. Endocrinol. (Oxf.) 19:405-413.

Grala, T. M., M. C. Lucy, C. V. C. Phyn, A. J. Sheahan, J. M. Lee, and J. R. Roche. 2011. Somatotropic axis and concentrate supplementation in grazing dairy cows of genetically diverse origin. J. Dairy Sci. 94:303-315

Grala, T. M., J. R. Roche, J. K. Kay, A. G. Rius, H. M. White, S. S. Donkin, M. D. Littlejohn, R. G. Snell, and C. V. C. Phyn. 2014. The expression of genes involved in hepatic metabolism is altered by temporary changes to milking frequency. J. Dairy Sci. 97:838-850.

Hales, C. N., and P. J. Randle. 1963. Immunoassay of insulin with insulin-antibody precipitate. Biochem. J. 88:137-146.

Hammond, V. A., and D. G. Johnston. 1987. Substrate cycling between triglyceride and fatty acid in human adipocytes. Metabolism 36:308-313.

Hellemans, J., G. Mortier, A. De Paepe, F. Speleman, and J. Vandesompele. 2007. qBase relative quantification framework and software for management and automated analysis of real-time quantitative PCR data. Genome Biol. 8:R19.

Janovick, N. A., J. J. Loor, P. Ji, R. E. Everts, H. A. Lewin, S. L. Rodriguez-Zas, and J. K. Drackley. 2009. Overfeeding energy prepartum dramatically affects peripartal expression of mRNA transcripts in subcutaneous adipose tissue compared with controlling energy intake prepartum. J. Dairy Res. 92(E-Suppl. 1):709.

Jiang, H., Y. Wang, M. Wu, Z. Gu, S. J. Frank, and R. Torres-Diaz. 2007. Growth hormone stimulates hepatic expression of bovine growth hormone receptor messenger ribonucleic acid through signal transducer and activator of transcription 5 activation of a major growth hormone receptor gene promoter. Endocrinology 148:3307-3315.

Kalderon, B., N. Mayorek, E. Berry, N. Zevit, and J. Bar-Tana. 2000. Fatty acid cycling in the fasting rat. Am. J. Physiol. Endocrinol. Metab. 279:E221-E227.

Kay, J. K., C. V. C. Phyn, A. G. Rius, S. R. Morgan, T. M. Grala, and J. R. Roche. 2013. Once-daily milking during a feed deficit decreases milk production but improves energy status in early lactating grazing dairy cows. J. Dairy Sci. 96:6274-6284.

Kennedy, G. C. 1953. The role of depot fat in the hypothalamic control of food intake in the rat. Proc. R. Soc. Lond. B Biol. Sci. 140:578-592.

Khan, M. J., A. Hosseini, S. Burrell, S. M. Rocco, J. P. McNamara, and J. J. Loor. 2013. Change in subcutaneous adipose tissue metabolism and gene network expression during the transition period in dairy cows, including differences due to sire genetic merit. J. Dairy Sci. 96:2171-2182. http://dx.doi.org/10.3168/jds.20125794.

Kobayashi, Y., C. K. Boyd, C. J. Bracken, W. R. Lamberson, D. H. Keisler, and M. C. Lucy. 1999. Reduced growth hormone receptor (GHR) messenger ribonucleic acid in liver of periparturient cattle is caused by a specific down-regulation of GHR 1A that is associated with decreased insulin-like growth factor I. Endocrinology 140:3947-3954.

List, E. O., D. E. Berryman, K. Funk, E. S. Gosney, A. Jara, B. Kelder, X. Wang, L. Kutz, K. Troike, N. Lozier, V. Mikula, E. R. Lubbers, H. Zhang, C. Vesel, R. K. Junnila, S. J. Frank, M. M. Masternak, A. Bartke, and J. J. Kopchick. 2013. The role of GH in adipose tissue: Lessons from adipose-specific GH receptor gene-disrupted mice. Mol. Endocrinol. 27:524-535. http://dx.doi. org/10.1210/me.2012-1330.

Loiselle, M. C., C. Ster, B. G. Talbot, X. Zhao, G. F. Wagner, Y. R. Boisclair, and P. Lacasse. 2009. Impact of postpartum milking frequency on the immune system and the blood metabolite concentration of dairy cows. J. Dairy Sci. 92:1900-1912.

Lucy, M. C., C. K. Boyd, A. T. Koenigsfeld, and C. S. Okamura. 1998. Expression of somatotropin receptor messenger ribonucleic acid in bovine tissues. J. Dairy Sci. 81:1889-1895.

Lucy, M. C., G. A. Verkerk, B. E. Whyte, K. A. Macdonald, L. Burton, R. T. Cursons, J. R. Roche, and C. W. Holmes. 2009. Somatotropic axis components and nutrient partitioning in genetically diverse dairy cows managed under different feed allowances in a pasture system. J. Dairy Sci. 92:526-539.

McGuire, M. A., D. E. Bauman, D. A. Dwyer, and W. S. Cohick. 1995. Nutritional modulation of the somatotropin/insulin-like growth factor system: Response to feed deprivation in lactating cows. J. Nutr. 125:493-502.

McNamara, J. P. 1991. Regulation of adipose tissue metabolism in support of lactation. J. Dairy Sci. 74:706-719.

McNamara, J. P., and J. K. Hillers. 1986. Regulation of bovine adipose tissue metabolism during lactation. 2. Lipolysis response to milk production and energy intake. J. Dairy Sci. 69:3042-3050.

McNamara, S., J. J. Murphy, F. P. O'Mara, M. Rath, and J. F. Mee. 2008. Effect of milking frequency in early lactation on energy metabolism, milk production and reproductive performance of dairy cows. Livest. Sci. 117:70-78.

Millward, C. A., D. DeSantis, C.-W. Hsieh, J. D. Heaney, S. Pisano, Y. Olswang, L. Reshef, M. Beidelschies, M. Puchowicz, and C. M. Croniger. 2010. Phosphoenolpyruvate carboxykinase (PCK1) helps regulate the triglyceride/fatty acid cycle and development of insulin resistance in mice. J. Lipid Res. 51:1452-1463.

Patton, J., D. A. Kenny, J. F. Mee, F. P. O'Mara, D. C. Wathes, M. Cook, and J. J. Murphy. 2006. Effect of milking frequency and diet on milk production, energy balance, and reproduction in dairy cows. J. Dairy Sci. 89:1478-1487.

Phyn, C. V. C., J. K. Kay, A. G. Rius, S. R. Morgan, C. S. Roach, T. M. Grala, and J. R. Roche. 2011. Effect of temporary alterations to milking frequency during the early post-partum period on milk production and body condition score in grazing dairy cows. Proc. N. Z. Soc. Anim. Prod. 71:45-49. 
Rhoads, R. P., J. W. Kim, B. J. Leury, L. H. Baumgard, N. Segoale, S. J. Frank, D. E. Bauman, and Y. R. Boisclair. 2004. Insulin increases the abundance of the growth hormone receptor in liver and adipose tissue of periparturient dairy cows. J. Nutr. 134:1020-1027.

Rhoads, R. P., J. W. Kim, M. E. Van Amburgh, R. A. Ehrhardt, S. J. Frank, and Y. R. Boisclair. 2007. Effect of nutrition on the GH responsiveness of liver and adipose tissue in dairy cows. J. Endocrinol. 195:49-58. http://dx.doi.org/10.1677/JOE-07-0068.

Rocco, S. M., and J. P. McNamara. 2013. Regulation of bovine adipose tissue metabolism during lactation. 7. Metabolism and gene expression as a function of genetic merit and dietary energy intake. J. Dairy Sci. 96:3108-3119.

Roche, J. R., P. G. Dillon, C. R. Stockdale, L. H. Baumgard, and J. M. VanBaale. 2004. Relationships among international body condition scoring systems. J. Dairy Sci. 87:3076-3079.

Soberon, F., J. L. Lukas, M. E. Van Amburgh, A. V. Capuco, D. M. Galton, and T. R. Overton. 2010. Effects of increased milking frequency on metabolism and mammary cell proliferation in Holstein dairy cows. J. Dairy Sci. 93:565-573.
Sumner, J. M., and J. P. McNamara. 2007. Expression of lipolytic genes in the adipose tissue of pregnant and lactating Holstein dairy cattle. J. Dairy Sci. 90:5237-5246.

Vandesompele, J., K. De Preter, F. Pattyn, B. Poppe, N. Van Roy, A. De Paepe, and F. Speleman. 2002. Accurate normalization of real-time quantitative RT-PCR data by geometric averaging of multiple internal control genes. Genome Biol. 3:research0034.

Verbyla, A., B. Cullis, M. G. Kenward, and S. J. Welham. 1999. The analysis of designed experiments and longitudinal data by using smoothing splines. J. R. Stat. Soc. Ser. C Appl. Stat. 48:269-311.

Vernon, R. G., and C. M. Pond. 1997. Adaptations of maternal adipose tissue to lactation. J. Mammary Gland Biol. Neoplasia $2: 231-241$.

Vijayakumar, A., R. Novosyadlyy, Y. Wu, S. Yakar, and D. LeRoith. 2010. Biological effects of growth hormone on carbohydrate and lipid metabolism. Growth Horm. IGF Res. 20:1-7.

Wang, T., Y. Zang, W. Ling, B. E. Corkey, and W. Guo. 2003. Metabolic partitioning of endogenous fatty acid in adipocytes. Obes. Res. 11:880-887. 